\title{
DEVELOPMENT OF DIGITAL BASED TENNIS FOOTWORK INSTRUMENTS
}

\author{
Andika Prabowo', Septian Raibowo², Yahya Eko Nopianto ${ }^{3}$, Januar Sahri ${ }^{4}$ \\ Universitas Bengkulu ${ }^{123}$, Universitas Negeri Padang ${ }^{4}$ \\ Andikaprabowo@unib.ac.id
}

\begin{abstract}
The problem in this research is the absence of the test instrument leg movements (Footwork) in the field of learning tennis is effective, efficient and modern. The purpose of this study was to design a test instrument leg movements (Footwork) in the field of learning tennis sport that is effective, efficient, modern and can be used to support learning Footwork attennis club, or college sports. This type of research is research and development Research and Development. The stages of developing this test instrument are observation in order to see potential problems, information / data collection, product design, design validation, design improvement, product testing, product revision, usage testing, product revision, mass production. The results of this study are for expert validity. tennis court obtained an assessment percentage of $97.5 \%$. These results indicate that according to the field tennis expert the test instrument footwork digital-basedhas the "Good / Feasible" category, while the results of the expert validation and measurement results obtained a $95 \%$ percentage of the assessment, it can be concluded that according to the test and measurement experttest instrument. footwork, this digital-basedhas a category of "Good / Feasible", and the results of the calculation of reliability using thetechnique test and, retest the $r$ value is 0.998 , so it can be said that the correlation is "high and significant", it can be concluded that thetest instrument footwork digitalbasedis good to be used as a measuring tool to measurefootworkin tennis court lessons.
\end{abstract}

Keywords: Instruments, Footwork, Tennis, Digital

Accepted: 9th of July 2021

Correspondence author: Andika Prabowo, Universitas Bengkulu, Indonesia. E-Mail: Andikaprabowo@unib.ac.id

DOI http://dx.doi.org/10.31851/hon.v4i25377

Jurnal Halaman Olahraga Nusantara licensed under a Creative Commons Attribution-ShareAlike 4.0 International License.

\section{INTRODUCTION}

Sports are activities that are systematic and can encourage, nurture and develop physical and spiritual potential. Sports continues to develop rapidly in line with the development of modernization and increasingly sophisticated technology with various characteristics in the form of needs, activities, and lifestyle (Lauh et al., 2020). Sports in the community are not only for the sake of 
achievement, recreation and physical fitness, but also as a means of education. Achieving maximum learning outcomes is the right reason to support development in the field of sports, especially in the procurement of sports facilities and infrastructure as an effective, efficient and modern sports learning medium. In Republic of Indonesia Law Number 3 of 2005 concerning the National Sports System, CHAPTER II Article 4 states that "National sports aim at maintaining and enhancing freshness and fitness, achievement, human quality, instilling moral values and noble morals, disciplinary sportsmanship, strengthening and fostering unity and national unity, strengthen national resilience and increase the dignity and honor of the nation". Effort to support the best possible sports education is the main goal of educational sports, one of which is the sport taught in tertiary institutions is the sport of tennis court. By advancing the sports learning system, one of which is developing innovation products in the field of sports, it can be said that we have participated in making the nation and state proud in the field of sports education. The game of tennis is a court games played on a rectangular field and separated into 2 (two) parts by the net and using tools in the form of a racket and ball (Raibowo et al., 2020). The aim of the game of tennis in general is for health and fitness but the specific goal is to score as many points as possible by dropping the ball into the opponent's area and driving the ball into his own area to achieve victory.

The best performance of athletes is the result of the coaching provided to athletes through well-programmed and targeted exercises. Coaching in sport is a conscious effort that is carried out in a systematic manner to achieve sports goals (Lesmana, 2019). High achievement is achieved not only because of the athlete's talent, but also because of external factors, namely training. Exercise is a very important factor in the effort to hone these talents to the maximum, therefore training must be done intensively and programmed (Pratiwi \& Anggara, 2021)

In the world of education, tennis learning has been carried out for a long time, various types of techniques are studied in sports colleges, these techniques require good basic movement skills, in tennis there are aspects of basic motion 
that are very important, according to Gusril (2017), basic motion includes the following

1. Locomotor motion, which is motion that moves from one place to another, in tennis, for example, such as stepping, shifting, running and jumping.

2. Non-locomotor motion, which is motion that does not move places, in tennis, for example reaching out.

3. Manipulative movements, which are usually described as coordinated movements of the feet and hands.

From these basic movements, an athlete / tennis player can easily perform techniques in tennis court. Before starting to introduce and practice basic techniques, there is one fundamental component that must be mastered first, namely coordination (Arifianto \& Raibowo, 2020). Then, coordination coordination, one of the techniques that is no less important in playing tennis, is the technique of footwork or leg movements. Footwork can be interpreted as the ability to regulate footwork in carrying out the task of returning the ball to the opponent's court, so it can be concluded that footwork is a technique to regulate foot movement in tennis court, the better the footwork of a tennis athlete, the better the tennis player will look (Anggraini et al., 2020). In the world of education, usually the lecturer will provide manual instruction in tennis court footwork, where students will be taught to move from the middle of the field in the power area to the right side, left side, front of the net, oblique right to left, oblique behind right, and oblique behind left, the movement is carried out randomly in order to train the footwork of a tennis player in facing the real game, based on this description, it can be seen that manual footwork training not only seems old-fashioned, but much more than that can cause the slow process of learning techniques. the slow goal of achieving achievement,

With these weaknesses, it becomes a problem because in the game of tennis, the agility of the footwork is required in the field (Footwork). So, to overcome this, it is necessary to have new innovations in the form of developing 
supporting tools for training or learning media that are more practical, effective and efficient (Kardiawan et al., 2018). In the field of sports, there have been many training approaches with the help of technology, one of which is the use of technology in the form of digital sensors on the measurement results of vertical jumps (Prabowo et al., 2020).

The development with the advancement of science and technology, this can be seen in the techniques, tactics and infrastructure that greatly support the progress and development of sports, therefore there are strong reasons for researchers to examine these developments. digital based tennis footwork test instrument.

The ability to cultivate feet in the game of tennis is very important to master, to become a reliable player. Ability can facilitate the implementation of skills motion (Arisman \& Agun Guntara, 2021). Playing skills will be good if supported by adequate leg movement for each type of play. The very fast movement of the ball in the tennis court game forces the players to react quickly in returning or making an attack to the opponent. Returns or strikes are best when supported by good footwork. Footwork begins with a stance in waiting for the ball from the opponent's hit. If when your opponent hits the ball, his position is slightly to the right of the field then you have to move to the left, and vice versa. This is so that we can cover the empty space that is the target point of the opponent's hit. Thus, we don't need a few steps to be able to return the ball from the opponent's hit. The closer to our standing position to the direction the ball is coming from, the easier it will be for us to hit the ball. Conversely, the farther the ball comes from our position, the more difficult it will be for us to return the ball. This is because we need a few steps quickly to be able to hit the ball correctly as desired. The number of steps required to move quickly is highly dependent on mastery of the footwork.

Footwork is to get closer to the position where the ball falls in the controlled field so that players can make strokes easily towards the opponent's field of control, the goal of agile leg movements is so that players can move as 
efficiently as possible to all parts of the field and be able to perform Forehand and Backhand movements as well as possible (Utama et al., 2020). It's good so that the ball that is hit by the opponent can be returned as well as possible so that players can score and achieve victory, agility in foot movement is one of the requirements so that someone can play tennis well (Wong et al., 2020). Because foot agility is a requirement in playing tennis, therefore a good instrument is needed to train the footwork movement, and the developed instrument will certainly have an effect on improving footwork abilities and improving learning outcomes of tennis court footwork in tertiary institutions.

Based on the results of Ulha \& Hermanzoni (2018), it is said that there is a significant effect of footwork training on groundstroke ability, obtained an average of 14.14 in the pre-test to 17,43 on the post-test (tcount $2.304>$ ttable 1.94). This proves that footwork training is very important in order to achieve good tennis playing skills and in learning this technique is very important to teach because this technique is a very important technique in playing tennis. Also according to the results of (Hardiansyah, 2019) entitled The Effect of Exercise Using Video on the Ability of Table Tennis Footwork, revealed that training using video has a significant effect on the footwork ability of students in the Table Tennis Sports Activity Unit of Padang State University, this explains that footwork has a major influence in improving the ability of tennis players, both tennis and table tennis.

With the importance of the footwork technique, the training must be maximized, one of which is the use of effective, efficient and modern tools, in the field it can be found that there are still many clubs or campuses that are learning tennis court footwork using the manual method without the help of effective tools, This is due to the absence of instruments that support the exercise, therefore due to the absence of modern tennis footwork training instruments, the researcher offers a solution in the form of a digital-based tennis footwork test instrument that is more modern, effective and efficient. Video technology device as a facilitator for interaction between coaches (Okilanda et al., 2021). 


\section{HALAMAN Jendral A. Yani Street Lorong Gotong Royong 9/10 Ulu

\section{METHOD}

This type of research is research and development. This research and development method is a research method used to produce certain products and test the effectiveness of the product (Komaini et al., 2018). This study aims to create a digital-based footwork test instrument in tennis, this is done to make it easier for athletes and coaches to improve their ability to exercise footwork in tennis and also facilitate the learning process of tennis footwork in sports colleges. The research steps in research and development consist of (1) potential problems, (2) information / data collection, (3) product design, (4) design validation, (5) design improvement, (6) product testing, (7) product revision, (8) usage trial, (9) product revision, (10) mass product. However, in this study the researcher was limited to step (7), namely product revision.

In the research process, observations were made to collect information on potential problems, after which data collection was carried out by interviewing students who were learning tennis court footwork using the manual method so that complaints were obtained in the form of boredom and less interesting learning that only used manual media, after which the researcher made a design. digital footwork instruments, and validating the design by distributing questionnaires to tennis court experts and measurement test experts, after getting results and input from experts, the researchers entered the next stage, namely design revisions based on input from experts, after which the researchers conducted product trials. The 40 participants who came from FIK UNP Coaching Department students used the tool and obtained the first trial data, after which the researcher could see the shortcomings of the instruments made so that researchers could make product revisions. This research was only conducted up to the 7th stage of the Research and Development research.

Design validation is an activity process to assess whether the product design describes fundamental changes from previous designs carried out by experts or experts relevant to the scientific field and the products produced, expert 
validation questionnaire data is processed by looking for the percentage of instrument validation and adjusted to existing norms.

$$
\text { Eligibility Percentage (\%) } \frac{\text { Score obtained }}{\text { Expected score }} \text { 100\% }
$$

The results of these calculations are then used to determine the feasibility of the tool being developed by using the division of the range of categories stated (Arsil, 2004).

Table 1. Percentage Criteria

\begin{tabular}{ccc}
\hline NO & Kriteria & Presentase (\%) \\
\hline 1 & Very good & $81-100$ \\
2 & Good & $61-80$ \\
3 & Enough & $41-60$ \\
4 & Less & $21-40$ \\
5 & Very Less & $0-20$ \\
\hline
\end{tabular}

The reliability test on this tool is used to see the level of reliability of the tool by using the test and retest method with the statistical calculation of the produck moment (Ali, 2012).

Table 2. Reability Level

\begin{tabular}{cc}
\hline Interval Koefisien Korelasi & Reliability \\
\hline $0,00-0,199$ & Very weak \\
$0,20-0,399$ & Weak \\
$0,40-0,599$ & Moderate \\
$0,60-0,799$ & Strong \\
$0,80-1,00$ & Very strong \\
\hline
\end{tabular}

\section{RESULT AND DISCUSSION}

\section{Research Result}

This study produces a tennis court footwork instrument that has a good level of validity and reliability. From the results of expert validation, the percentage of the assessment was $97.5 \%$, this result indicates that according to the field tennis expert, the digital-based footwork test instrument has the category of "Good / Feasible", while the results of expert validation and measurement obtained a percentage of $95 \%$ It can be concluded that according to the test and measurement experts, this digital-based footwork test instrument has the "Good / Feasible" category. It can be concluded that the digital-based footwork test 
instrument is good for using as a measuring tool to measure footwork in tennis court learning. The results of the calculation of reliability using the test and retest technique obtained $r$ value of 0.998 , so it can be said to have high and significant correlation. The development of this digital-based footwork instrument is in the form of a tool used to perform footwork exercises or learning using measurement media in the form of an infrared sensor which has a high sensitivity to movement so it is very suitable for use as a training medium for tennis footwork. This footwork instrument development product was developed to provide a more modern, effective and efficient learning experience in the learning process of tennis court footwork.

\section{Discussion of Research Results}

The development of this digital technology-based tennis footwork instrument requires measurement equipment and electronic components, such as Power supply, Mini Segway Smart Balance Wheel Scooter Pressure Sensor Stepping ESC, 12V Programmable PIR Timer with Override, ATmega328 mocrocontroler and Arduino Uno Rev 3, interfacing and display circuit. (LCD) as a digital reading display that will be assembled and connected using a USB 3.0 cable to produce output data in the form of how many sensors are stepped on correctly every one minute.

The ATmega328 microcontroller belongs to the CMOS 8 Bit family of low power microcontrollers based on Risk Architecture, with an instruction execution time of 1 machine cycle. The reception system by the Atmega328 Microcontroller is almost 1MIPS per MHz. This microcontroller is designed to optimize power consumption for processing speed. Atmega328 microcontroller provides: Data and program memory 8 KByte In-System Programable Flash, 512 Byte EEPROM (Electrically Erasable Programmable Read-Only Memory), 1 Kbyte SRAM, 23 general purpose I/O lines, 32 general purpose working registers, 3 flexible timers/Counters, Internal and External Interrupts, USART programming serial, 6-channel ADSC. 
LCD is a layer of an organic mixture between a clear glass layer and a transparent indium oxide electrode in the form of a seven-segment display and an electrode layer on the back glass. When the electrodes are activated by an electric field (voltage), the long, cylindrical organic molecules adjust to the electrodes of the segment. The sandwich layer has a front vertical light polarizer and a rear horizontal light polarizer followed by a reflector layer. The reflected light cannot pass through the adjusted molecules and the activated segment appears to darken and form the character of the data you want to display (Ihsan et al., 2020). E18D80NK Adjustable Infrared Sensor Switch $3-80 \mathrm{~cm}$ is a sensor to detect objects that can reflect Infrared rays, (solid and not transparent). We can set the detection distance from $3 \mathrm{~cm}-80 \mathrm{~cm}$ so that we can also use it as a certain distance sensor. This sensor will calculate the number of stamps based on the sensor number from sensor one to sensor eight.

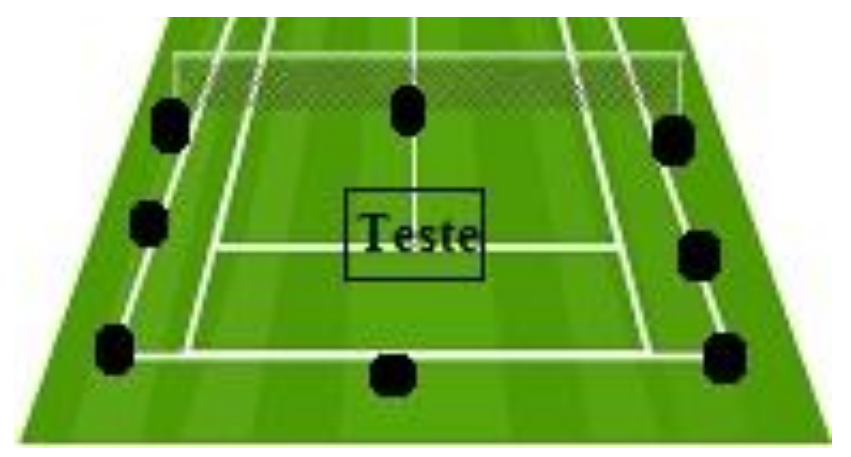

Figure 1. Positioning of the test equipment

This tool is in the form of puzzel plates totaling eight colorful box-shaped puzzels that have connecting cabins with other puzzels, where each of these cabals is connected to an LCD on the edge of the field and there is a program connected to a laptop that displays footwork directional movements displayed on the infocus is displayed on the folding screen, so that athletes or students who try this tool will follow the movements according to the directions on the monitor screen accompanied by the voice of the guide, this footwork movement is carried out for one minute and the calculated movement is the right movement according to the direction program on the monitor screen. 


\section{OLAHRAGA \\ JURALHLHUKGOL DURAQHAT \\ Jendral A. Yani Street Lorong Gotong Royong 9/10 Ulu Palembang South Sumatera

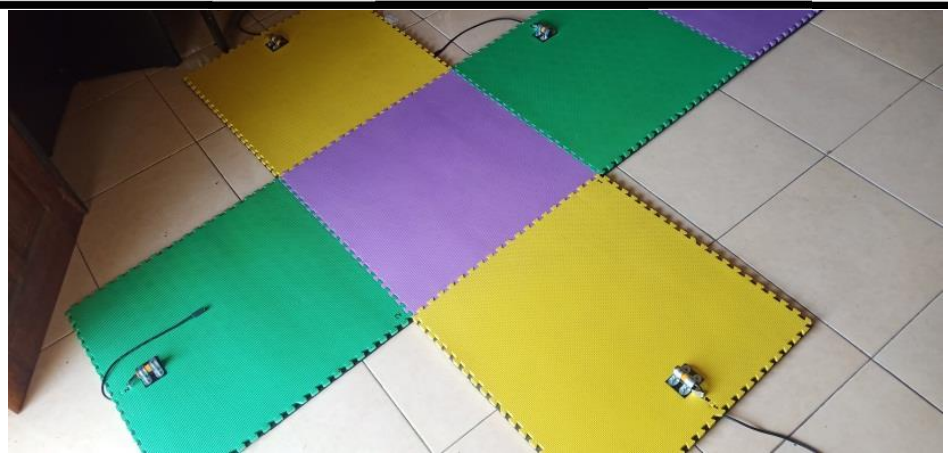

Figure 2. Display of Equipment Pieces and Infrared Sensors

The digital-based tennis footwork instrument has gone through the validity and reliability test stages so that this instrument is declared as a medium for training or learning tennis footwork. This digital-based tennis footwork instrument is useful for athletes, coaches and lecturers in the context of conducting training and learning tennis footwork. This sensor-based tennis footwork development product was developed using an infrared sensor that is connected to the Arardiuno Uno component which can produce a more sensitive and accurate motion count than the previous method, namely the manual method. The digital sensor can be used as an alternative to determine the speed of the tennis ball and the strength of the service when serving.(Kardiawan et al., 2018)

\section{CONCLUSION}

The digital-based tennis footwork instrument has gone through the validity and reliability test stages so that this instrument is declared as a medium for training or learning tennis footwork. This digital-based tennis footwork instrument is useful for athletes, coaches and lecturers in the context of conducting training and learning tennis footwork. This sensor-based tennis footwork development product was developed using an infrared sensor that is connected to the Arardiuno Uno component which can produce a more sensitive and accurate motion count than the previous method, namely the manual method. 


\section{REFERENCES}

Ali. (2012). Evaluasi Pembelajaran.

Anggraini, J. K., Ridwan, M., Fardi, A., \& Haryanto, J. (2020). Kontribusi

Koordinasi Mata Tangan, Kelentukan Pergelangan Tangan Dan Footwork

Dengan Ketepatan Backhand Drive. Sport Science: Jurnal Sains Olahraga

Dan Pendidikan Jasmani, 20(2), 107-121.

https://doi.org/0.24036/jss.v\%vi\%i.46

Arifianto, I., \& Raibowo, S. (2020). Model Latihan Koordinasi dalam Bentuk Video Menggunakan Variasi Tekanan Bola Untuk Atlet Tenis Lapangan Tingkat Yunior. STAND: Journal Sport Teaching and Development, 1, 4955. https://doi.org//10.36456/j-stand.v1i2.2671

Arisman, A., \& Agun Guntara, R. (2021). The Research Of Students' Motor Ability In Archery Extracurricular. Jurnal Maenpo: Jurnal Pendidikan Jasmani Kesehatan Dan Rekreasi, 11(1), 13. https://doi.org/10.35194/jm.v11i1.1216

Arsil. (2004). Pembinaan Kondisi Fisik. UNP Press.

Gusril. (2017). Pengembangan Motorik Pada Masa Anak-anak. UNP Press.

Hardiansyah, S. (2019). Pengaruh Latihan Menggunakan Video Terhadap Kemampuan Footwork Tenis Meja. Jurnal Pendidikan Dan Olahraga, 2(3), $1-5$.

Ihsan, N., Bafirman, Sujana, A., \& Permana, A. Y. (2020). Design of Instrument Explosive Power Leg Muscles Sensor Based. Journal of Physics: Conference Series, 1594(1). https://doi.org/10.1088/1742-6596/1594/1/012038

Kardiawan, I. K. H., Satyawan, I. M., \& Ariawan, K. U. (2018). Pengembangan Perangkat Alat Ukur Kekuatan Servis Bola Tenis Lapangan Berbasis Sensor Digital. Seminar Nasional Riset Inovatif 2018, 183-185.

Komaini, A., Sahri, J., \& Tohidin, D. (2018). Pengembangan Instrumen Tes Kelentukan Statis Berbasis Teknologi Sensor. Jurnal Sosioteknologi, 17(3), 343-349. https://doi.org/10.5614/sostek.itbj.2018.17.3.1

Lauh, W. D. A., Fallo, I. S., \& Dewi, U. (2020). Pengembangan Model Permainan Pembelajaran Renang Untuk Mahasiswa. Halaman Olahraga Nusantara (Jurnal Ilmu Keolahragaan), $\quad 3(2), \quad 173-187$. https://doi.org/10.31851/hon.v3i2.4476

Lesmana, H. S. (2019). Profil Delayed Onset Muscle Soreness (Doms) Pada 
Mahasiswa Fik UNP Setelah Latihan Fisik. Halaman Olahraga Nusantara (Jurnal Ilmu Keolahragaan), 50. https://doi.org/10.31851/hon.v2i1.2464

Okilanda, A., Dlis, F., Humaid, H., Putra, D. D., Arisman, A., \& Muslimin, M. (2021). Defense Warm-Up Exercise Material for 13-Age Athlete Using Video Technology in Covid-19 Era. International Journal of Human Movement and Sports Sciences, 9(4), 629-634. https://doi.org/10.13189/saj.2021.090404

Prabowo, A., Ihsan, N., Barlian, E., \& Welis, W. (2020). Development of digital based vertical jump test instruments. Journal of Physics: Conference Series, 1481(1), 1-7. https://doi.org/10.1088/1742-6596/1481/1/012029

Pratiwi, E., \& Anggara, N. (2021). Pengembangan Model Passing Bawah Bolavoli Pada Atlet Pemula Universitas Islam Kalimantan MAB Banjarmasin. Halaman Olahraga Nusantara (Jurnal Ilmu Keolahragaan), 4(1), 23-37. https://doi.org/dx.doi.org/10.31851/hon.v4i1.5106

Raibowo, S., Adi, S., \& Hariadi, I. (2020). Efektivitas dan Uji Kelayakan Bahan Ajar Tenis Lapangan Berbasis Multimedia Interaktif. Jurnal Pendidikan: Teori, Penelitian Dan Pengembangan, 5(7), 944-952. https://doi.org//10.17977/jptpp.v5i7.13726

Ulha, I., \& Hermanzoni. (2018). Pengaruh Latihan Footwork Terhadap Kemampuan Groundstroke. Jurnal Patriot Olahraga, 2(3), 313-319. https://doi.org/doi.org/10.24036/patriot.v0i0.49

Utama, A. M. B., Komari, A., Sunardianta, R., \& Marhaendro, A. S. D. (2020). Relationship between Ball Control, Footwork and Table Tennis Performance of College Students. 360-365. https://doi.org/10.5220/0009786503600365

Wong, D. W. C., Lee, W. C. C., \& Lam, W. K. (2020). Biomechanics of table tennis: A systematic scoping review of playing levels and maneuvers. Applied Sciences (Switzerland), 10(15). https://doi.org/10.3390/app10155203 